\title{
Analysis on The Function Construction of Engineering Project Management Informatization in Survey and Design Enterprises
}

\author{
Bing-Ying XIE \\ Department of Civil Engineering and Architecture \\ Panzhihua University \\ Panzhihua, China \\ e-mail: 121737250@qq.com
}

\author{
Jian FU \\ Panzhihua, China \\ e-mail: 33107698@qq.com
}

\author{
Qian ZHANG \\ Department of Civil Engineering and Architecture \\ Panzhihua University \\ Panzhihua, China \\ e-mail: 418677556@qq.com
}

Department of Civil Engineering and Architecture

\begin{abstract}
China's survey and design industry as an integral part of traditional industries should be through technological innovation, service innovation, management innovation, and constantly improve the survey and design of the project quality and service level, innovative industry model to meet today's increasingly fierce market competition and the needs of the new situation. This paper mainly analysis on the module and mode of project management information function construction in survey and design enterprises from the perspective of project management informationization.
\end{abstract}

Keywords-survey and design enterprises; project; management informationization; construct

\section{INTRODUCTION}

The twenty-first century is the era of the rapid development of modern information technology, information resources have the same strategic position as traditional energy, and information technology has become the key to improve the core competitiveness of enterprises. Ministry of Construction in the "National Engineering Survey and Design Industry $2000 \sim 2005$ Computer Application Engineering and Information Development Plan" (Construction [19991314]), it proposed that the survey and design units should be built the integrated application system, which to support the network, It integrates the design and management of the main line based on the network as the support, the professional CAD technology application, the engineering information management as the core and the project management ${ }^{[1]}$.

\section{Summary of Project Management INFORMATION}

\section{A. The Concept of Project Management}

The name of the project management was first started with the Manhattan program, in the 1950s it introduced by Professor Loo-Keng Hua to China. The definition of project management is the construction unit to use the system engineering point of view, theory and method of the whole process of the project, all-round management. Project management should be carried out in a scientific, procedural and institutionalized approach to project management. Project management can also refer to the owners of the unit commissioned by the qualified project management unit, according to the contract work tasks and work content, managing project scientifically and comprehensively.

According to the actual situation of the specific project production organization, project management can be divided into the project management of the owner, the project management of the construction side, the project management of the supplier, the project management of the design side, the project management of the general contractor and the project management of the other project participants.

\section{B. The Concept of Engineering Project Management Informatization}

Informatization refers to the social and economic development from the material and energy for the economic structure of the focus, to the process of changing the focus of information and knowledge on the economic structure ${ }^{[2]}$. In the process of transformation of this economic structure, needing to put modern technology and equipment and modern information technology into all areas of socioeconomic, and thus continue to improve social labor productivity.

Project management information is refers to the advanced fine management as a fundamental to the flow of goods and database as the main line to the capital flow and workflow as the core, in the advanced information technology support for project management innovation and practice, and developing, collecting and using of various information resources of the project, the establishment of the project information platform and database, in the construction of the entire life cycle of the project strive to the lowest production costs, to achieve the highest project 
benefits, and to manage the project management innovation and technical support platform.

\section{THE FUNCTION AND SIGNIFICANCE OF} ENGINEERING PROJECT MANAGEMENT INFORMATIZATION

\section{A. The Significance of Project Management Informationization}

According to the relevant international literature, the project in the whole process of building problems, in which ,two-thirds of the issues related to information exchange, The increase in the cost of $10 \%$ to $33 \%$ of the project is related to the exchange of information, especially in large projects, information exchange problems lead to engineering design changes and information exchange problems lead to the implementation of the project error, accounting for the total cost of the project $3 \%$ to $5 \%{ }^{[3]}$.

The information management of project management plays an important role in improving the project management efficiency, improving the quality of the project, reducing the project cost, accumulating the information resources and improving the market competitiveness of the enterprise. Such as, the project can use information technology to establish information management, communication and communication platform. Through the information technology platform to achieve efficient management of the project, Use project management data to provide a variety of project information to achieve the project coordination and control of the remote. Using information technology to promote the reconstruction of project management, through the implementation of information management project, can improve work efficiency and reduce the strength of the management staff. The use of information technology and information platform to achieve intensive office can reduce communication costs. The use of information resources can be timely access to new projects and new technology.

\section{B. The Significance of Project Management Informatization in Survey and Design Enterprises}

In the information technology, especially in the context of project management information, foreign industrial developed countries and regions, for the survey and design industry information, has taken a series of important initiatives to achieve the survey and design industry information, especially the project management information. Such as the United States and the European Union countries in the coordination of basic research, that carried out large-scale technical research. Singapore has achieved network management of government investment projects through technological innovation and industry change. Then, project approval, document transmission, information feedback and resource sharing, etc. can be achieved through information technology and network technology [1].

China's survey and design industry information construction since the reform and opening up, although has gone through 30 years of development, but with foreign industrial developed countries there is a big gap. China's survey and design enterprises should adapt to the needs of the new situation, combined with the actual situation of industry development, adhere to the information technology, management information and information technology personnel training as the core, professional and technical software as a platform to break through the development of traditional industries model, innovative survey and design business development model, and strive to promote the survey and design industry innovation, survey and design enterprises in the new situation of international competitiveness will be improved.

\section{The Function CONSTRUCTION OF PROJECT MANAGEMENT INFORMATIZATION IN SURVEY AND DESIGN ENTERPRISES}

For the survey and design enterprises, the whole process and all-round information construction has become a development model for survey and design enterprises in international [1]. According to the business process of survey and design enterprises, it is can be see that the function construction of project management information of survey and design enterprises mainly embodies several aspects, the business process of the survey and design enterprise is shown in Figure1.

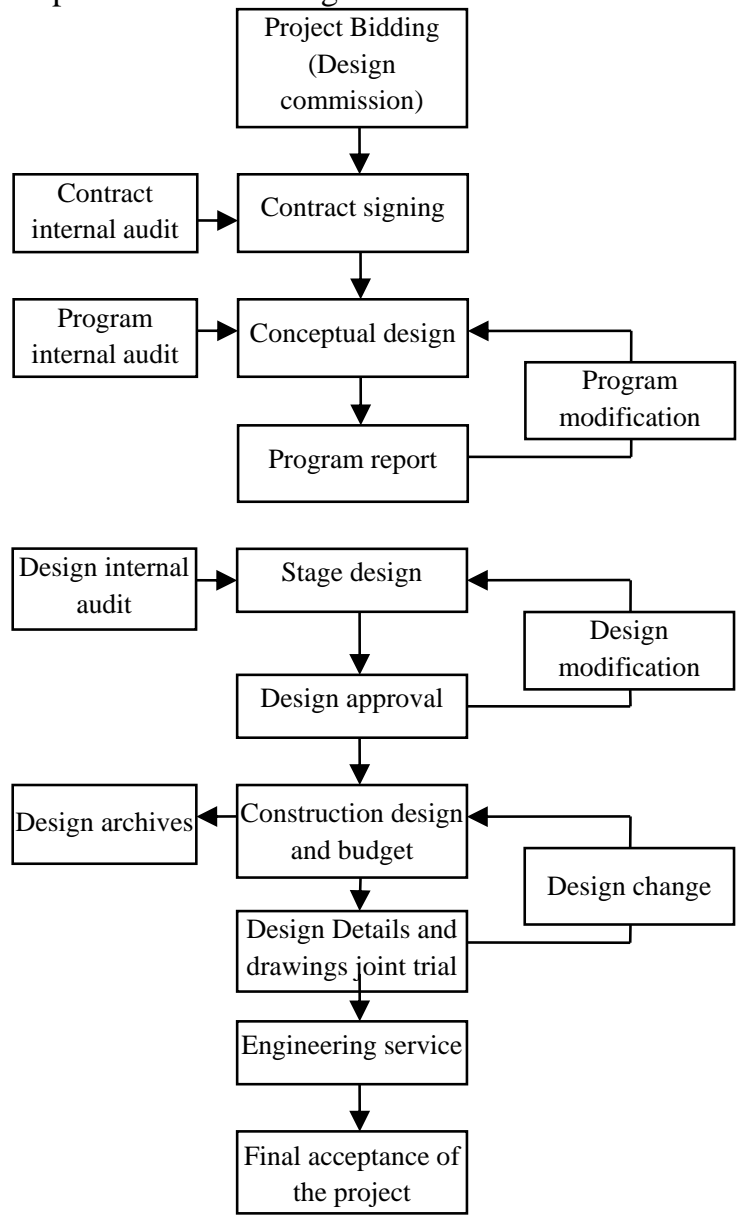

Figure1. Survey and design business process flow chart 


\section{A. Contract Management Informatization}

Survey and design enterprises should first use modern information technology to establish the whole process of contract management information database, from the project information collection to the project tracking bid until the completion of the project contract. Second, the contract management information should have the project contract information account entry function, at the same time to complete the contract review management and the contract approval function.

\section{B. Collaborative Design Information}

Survey and design enterprise project collaborative design information technology should use information technology, establish collaborative design of virtual network, collaborative design communication software and platform, achieve the professional, the designers of efficient communication and communication, also achieve a unified sharing of project resources and download. Business management software and professional design software were get together to achieve software updates and the use of consistency.

\section{Progress and Quality Management Information}

Investigation and design enterprise project schedule management information should use information technology, establishing enterprise design project progress management information system, it include the progress of the project plan, the key progress of the project to remind the project schedule adjustment and other modules, in order to achieve the whole process of design project tracking management information.

Investigation and design enterprise project quality management information should use information technology, establishing enterprise design project quality management information system, it include design projects and design changes sub-professional proofreading, audit, validation module and design project quality information query module, to achieve the quality of the design project management information.

\section{Budget Management Information}

Survey and design enterprise budget management informatization should process the project budget, identify the responsibilities of the departments in the enterprise budget management and be implemented by the budget management committee. Establishing various departments of the budget preparation template, re-combing the company's budget and sub-subjects, for the most important detailed budget and summary budget, the subjects should be collected to sort out, the authority to be controlled ${ }^{[5]}$. Using of information technology to achieve the intelligence of the budget software to achieve the sharing of budget resources and other information resources.

\section{E. Design Project Financial Management Informatization}

Survey and design enterprise design project financial management information can use the enterprise financial software platform to establish the design project financial management sub-information system, it includes the design project contract price, the proportion of the progress of the design fee, the proportion of the proportion of the project participants to mention the commission, the designer commission payment, design fees and other modules. The progressive realization of the design project design cost transparency.

\section{F. File Management Information}

Survey and design enterprise project file management information should use information technology and information platform, realize the unified management of electronic archives and paper archives of survey and design projects. The standardized management of electronic archives improves the effectiveness of enterprise archival information and the convenience of retrieval, and injects new vitality into the informationization of enterprise archives management. Then, the project file management information can improve the survey and design enterprise project file use efficiency, easy to coordinate the professional designers to carry out the construction of the project post-construction services. Survey and design enterprises through the development of file management and confidentiality measures, electronic file access control, electronic file network backup and disaster recovery system and other modern information technology to achieve the integrity of the project file and security.

\section{CONCLUSIONS}

In the context of current industry informatization and enterprise informatization, project management is faced with unprecedented challenges and opportunities, continuing innovation management model, adhering to the information management model. Survey and design enterprises in the engineering industry as a technical force, talent pool-based enterprises, should be based on their own actual situation, make full use of information technology and information resources, achieving the project management information innovation, through the implementation of project management information, and gradually achieving the international project information management model convergence. Improving the core competitiveness of survey and design enterprises continuously, it can meet the opportunities and challenges of the future information age.

\section{REFERENCES}

[1] Wang Suqing, Speeding up the Survey and Design of Enterprises and Strengthening the Core Competitiveness of Information Construction (Speech at the Seminar on Information Construction of National Survey and Design Enterprises) [J]. China Survey Design, vol. 12,pp.15-19, 2013.

[2] Liu Yonggang. Research and Application of Project Information Management System Construction [D]. Changsha,Hunan University, pp. 21-22,2010.

[3] Zhou Zhifeng. Research on the Application of Information Management in Construction Project [D]. Xiamen, Xiamen University, pp. 53-54,2012. 
[4] Jin Ling. Research on the Current Situation of Project Information Management and the Countermeasures $[\mathrm{J}]$. Chinese and foreign architecture, vol.12,pp. 121-122, 2010.
[5] Hu Xiaohuan, Gong Xia. information and practice of survey and design enterprise budget management [J]. China Survey Design, vol. 6,pp.93-94, June 2014. 